\title{
SUSCEPTIBILITY OF DIFFERENT CUCUMBER CULTIVARS TO SOME PESTS INFESTATION IN GIZA GOVERNORATE, EGYPT
}

\author{
ABD- ALLAH ${ }^{1}$, MARWA A. M., AZZA K. EMAM ${ }^{2}$, \\ H. E. M. HANAFY ${ }^{2}$ and A. R. I. HANAFY ${ }^{1}$. \\ 1- Plant Protection Research Institute, ARC, Dokki, Giza, Egypt \\ 2- Department of Plant Protection, Faculty of Agriculture, Ain Shams University, \\ Shoubra El- Kheima, Cairo, Egypt
}

(Manuscript received 29 March 2015)

\begin{abstract}
$\mathrm{F}$ ield and laboratory studies were carried out during two successive seasons (2012 and 2013) to study the susceptibility of seven cucumber cultivars (Fahd, PX 03648585, Bahi, CBA 911264 F1, Dora, CBA 910747 F1 and Nemsse) to infestation with Thrips tabaci (Lind.), Bemisia tabaci (Genn.), Aphis gossypii (Glover) and Tetranychus urticae (Koch). The results showed significant differences in the susceptibilities of the seven cultivars in both seasons. PX 03648585 cultivar was the most tolerant one to the infestation with the previous mentioned pests in both seasons while Bahi was the most susceptible one. Also, the determination of the content of some chemical components in the uninfested dry leaves of these cultivars was studied only for the summer season, 2013 to explain the differences in the susceptibilities of the tests cultivars. Studies showed significant positive correlation between the content of some chemical components and the different levels of infestations of the studied pests. The most susceptible cultivars, were positively correlated with high content of protein, carbohydrate, lipid and reducing sugar while the most tolerant one were contained mid or low amounts of these components.

Keywords: Seasonal abundance, Susceptibility of cucumber, Thrips tabaci, Bemisia tabaci, Aphis gossypii, Tetranychus urticae, Protein, Carbohydrate, Lipid, Reducing sugar
\end{abstract}

\section{INTRODUCTION}

Cucurbit plants are considered as important vegetable crops in Egypt. They have high nutritional value as they contain different vitamins " $A, B$ and $C$ ", sugar, starch, fats, proteins and minerals such as calcium, magnesium, potassium, sodium, phosphorous and iron. All these elements are essential for the body metabolism and vitality. This cucurbit plants are liable to be infested by numerous pests through seedling, flowering and fruiting stages. According to previous studies the most destructive pests infested cucumber plants are the cotton and onion thrips, Thrips 
tabaci (Lind.), the cotton and tomato whitefly, Bemisia tabaci (Genn.), the cotton aphid, Aphis gossypii (Glover) and the two spotted spider mite, Tetranychus urticae (Koch). It was mentioned that, these pests proved to have serious damage in leaves of cucumber plant by sucking cell sap which lead to great reduction in both quantity and quality of the yield. On the other hand, they cause indirect damage by transmitting virus diseases (Duffus, 1987). The currently unwise use of pesticides affected in destroying the natural enemies (Osman et al., 1985), environmental contamination and induce insect resistance. Therefore, it is necessary to use alternative method to suppress heavy infestation pests and to use in IPM programs. Marsaro Junior et al. (2009) found that the watermelon line sources showed different levels of resistance to A. gossypii infestations. The most susceptible, showed the higher number of nymphs/female after $24 \mathrm{~h}$ (8.17 nymphs). The most tolerant, proved lower number of nymphs/female, where the line sources 2, 10 and 25 were with 4.17, 4.08 and 3.50 individuals, respectively. Muzammil et al. (2005) explained the variability in cucurbit crops degree of $\mathrm{pH}$, nitrogen and protein contents and their influence on the population dynamics of whitefly.

So, the current investigation was mostly to select the lowest infested cultivars and the relation between the number of these pests and some chemical content of these different cultivars one of the control options to suppress heavy pests infestations in Integrated Pest Management (I.P.M.) programs.

\section{MATERIALS AND METHODS}

\section{Field study}

Field experiment was conducted for two successive growing seasons, 2012 and 2013 during summer plantation at Wardan Village, Giza Governorate.

Seven cucumber cultivars (Fahd, PX 03648585, Bahi, CBA 911264 F1, Dora, CBA $910747 \mathrm{~F} 1$ and Nemsse) were cultivated on $22^{\text {nd }}$ of April in about half feddan area to study their susceptibility to infestation with T. tabaci, B. tabaci, A. gossypii and $T$. urticae. The experimental area were divided into 7 plots, each plot represented one cultivar. Each cultivar area was divided into three replicates ( 3 plots). The design was completed in randomized block.

Two weeks (May $5^{\text {th }}$ ) after cultivation and during the growth period (12 weeks), weekly randomized samples of 210 leaves (10 leaves $\times 3$ replicates $\times 7$ cultivars) were taken early in the morning. The leaves were kept in tightly closed paper bags and transferred to the laboratory. The number of T.tabaci (adults + nymphs), B. tabaci (eggs + nymphs), A. gossypii (adults + nymphs) and T. urticae (eggs + nymphs+ 
adults) were examined by aid of stereomicroscope and counted on each tested cucumber cultivars during growing stages.

\section{Laboratory study}

\section{Biochemical studies}

Certain biochemical components were determined in dry uninfested leaves of the same previously seven cucumber cultivars to explain the relationship between some leaf chemical components and the degree of infestation with the mentioned pests.

The chemical analysis of leaf samples were conducted in Department of Insect Physiology, Plant Protection Research Institute, Agricultural Research Center. Total protein, total carbohydrate, total lipid and reducing sugar were determined according to Bradford (1976), Dubois et al. (1956) and Crompton and Birt (1967), Knight et al. (1972) and Sadasivam and Manickam (1991), respectively.

Statistical analysis was conducted by using SAS (1988) Program. F test used to evaluate the significant differences between treatments and mean separation was conducted using Duncan's multiple range test to arrange the tested cultivars in groups according to their susceptibility to infestation with the studied pests. The simple correlation was also used.

\section{RESULTS AND DISCUSSION}

It is clear from the obtained results in Table ( 1 ) that all of the tested cucumber cultivars were infested with Thrips tabaci (Lind.), Bemisia tabaci (Genn.), Aphis gossypii (Glover) and Tetranychus urticae (Koch) during $5^{\text {th }}$ of May until $21^{\text {st }}$ of July in 2012 and 2013.

\section{I- The susceptibility of seven cucumber cultivars to infestation with the aforementioned pests.}

\section{A- T. tabaci}

Data obtained in Table 1 showed the infestation degree with T. tabaci (nymphs + adults) to seven cucumber cultivars throughout seasons 2012 \& 2013. During the first season in 2012, Bahi and Nemsse proved significantly to be the highest infested cultivars with T. tabaci, with amounted of 169.08 and 158.91 individuals/30 leaves, respectively. On the contrary, Fahd and PX 03648585 cultivars were significantly infested with the lowest numbers showing seasonal mean counts of 127.16 and 129.16 individuals /30 leaves, respectively. While the cultivars CBA 911264 F1, Dora and CBA 910747 F1 had significantly the same sensitivity to the infestation with thrips. They were infested with seasonal mean counts of 149.91, 145.0 and 146.7 individuals /30 leaves, respectively. Concerning the second season 2013, although the statistical 
analysis revealed that no significant differences between the sensitivity of these cultivars to these pests, Bahi and CBA 910747 F1 cultivars showed the highest infestation degree with T. tabaci with mean counts of 143.91 and 140.91 individuals/ 30 leaves, respectively. On the other hand, the lowest infested cultivars were Fahd and PX 03648585 accounted for 124.41 and 129.08 individuals /30 leaves, respectively. The other three cultivars, CBA 911264 F1, Dora and Nemsse were infested with averages of $131.8,135.08$ and 138.50 individuals/ 30 leaves, respectively.

\section{B- B. tabaci}

Significant differences in the susceptibility of the tested cucumber cultivars to the infestation with B. tabaci (eggs+ nymphs) were found in both seasons, 2012 and 2013 (Table, 1). In the first season, the most susceptible cultivars were Bahi as the same as CBA 911264 F1 which harbored 167.83 and 159.33 individuals/30 leaves, respectively. Fahd, Dora, CBA 910747 F1 and Nemsse cultivars had moderate infestation, as they harbored 138.0, 150.58, 145.52 and 135.4 individuals /30 leaves, respectively. While PX 03648585 cultivar was the least one showing a seasonal mean count of 124.0 individuals/30 leaves. In the subsequent season, 2013, heavily infestation represented in Bahi cultivar (144.58 individuals /30 leaves), Moderately infestation was in Fahd (120.58), CBA 911264 F1 (129.08), Dora (135.58) and Nemsse (119.4) cultivars and the least infestation was in PX 03648585 (107.0) and CBA 910747 F1 (109.0 individuals/ 30 leaves).

\section{C- A. gossypii}

Data in Table 1 showed differences in aphid counts on the seven tested cucumber cultivars. In the first season, 2012, no significant differences between the counts of these pests on the different cultivars were found. The mean seasonal counts of this pest on leaves of cucumber cultivars, Fahd, PX 03648585, Bahi, CBA 911264 F1, Dora, CBA 910747 F1 and Nemsse were 20.16, 22. 8, 33.58, 28.91, 24.66, 25.75 and 31.58 individuals / 30 leaves, respectively. The corresponding counts of the pest in the second season, 2013 were $16.41,17.50,26.58,26.50,29.16,20.0$ and 28.41 individuals /30 leaves, respectively. Fahd, PX 03648585 and CBA 910747 F1 proved significantly, they were more tolerant to the infestation of this pest.

\section{D- T. urticae}

Table 1 showed the population densities of eggs and moving stages of $T$. urticae on leaves of seven cucumber cultivars in two seasons 2012 and 2013. The first season, the analysis showed that the differences 
Table 1. Mean numbers of T. tabaci, B. tabaci, A. gossypii and T. urticae on seven cucumber cultivars during two successive seasons 2012 and 2013, at Wardan, Giza Governorate

\begin{tabular}{|c|c|c|c|c|c|c|c|c|}
\hline \multirow{3}{*}{ cultivars } & \multicolumn{8}{|c|}{ Mean number/ 30 leaves } \\
\hline & \multicolumn{4}{|c|}{ Season 2012} & \multicolumn{4}{|c|}{ Season 2013} \\
\hline & T. tabaci & B. tabaci & A. gossypii & T. urticae & T. tabaci & B. tabaci & A. gossypii & T. urticae \\
\hline Fahd & $127.16^{\mathrm{b}}$ & $138.00^{\mathrm{bc}}$ & 20.16 & 159.00 & $124.41^{\mathrm{a}}$ & $120.58^{\mathrm{bc}}$ & $16.41^{\mathrm{bc}}$ & $156.58^{\mathrm{bc}}$ \\
\hline PX 03648585 & $129.16^{\mathrm{b}}$ & $124.00^{\mathrm{bc}}$ & 22.08 & 153.25 & $129.08^{\mathrm{a}}$ & $107.00^{c}$ & $17.50^{\mathrm{bc}}$ & $135.41^{\mathrm{c}}$ \\
\hline Bahi & $169.08^{\mathrm{a}}$ & $167.83^{\mathrm{a}}$ & 33.58 & 184.16 & $143.91^{\mathrm{a}}$ & $144.58^{\mathrm{a}}$ & $26.58^{\mathrm{ab}}$ & $169.00^{\mathrm{ab}}$ \\
\hline CBA 911264 F1 & $149.91^{\mathrm{ab}}$ & $159.33^{\mathrm{ab}}$ & 28.91 & 166.91 & $131.80^{\mathrm{a}}$ & $129.08^{\mathrm{abc}}$ & $26.50^{\mathrm{ab}}$ & $163.08^{\mathrm{ab}}$ \\
\hline Dora & $145.08^{\mathrm{ab}}$ & $150.58^{\mathrm{ab}}$ & 24.66 & 194.00 & $135.08^{\mathrm{a}}$ & $135.58^{\mathrm{ab}}$ & $29.16^{\mathrm{a}}$ & $183.91^{\mathrm{a}}$ \\
\hline CBA $910747 \mathrm{~F} 1$ & $146.70^{\mathrm{ab}}$ & $145.52^{\mathrm{abc}}$ & 25.75 & 173.66 & $140.91^{\mathrm{a}}$ & $109.00^{c}$ & $20.00^{b c}$ & $147.83^{\mathrm{bc}}$ \\
\hline Nemsse & $158.91^{\mathrm{a}}$ & $135.40^{\mathrm{bc}}$ & 31.58 & 179.16 & $138.50^{\mathrm{a}}$ & $119.41^{\mathrm{bc}}$ & $28.41^{\mathrm{a}}$ & $155.91^{\text {bc }}$ \\
\hline$F$ value & 2.58 & 2.57 & 1.59 & 1.71 & 0.70 & 2.99 & 3.32 & 2.86 \\
\hline Pr. $F$ & 0.0195 & 0.0199 & 0.1511 & 0.1190 & 0.64 & 0.007 & 0.0046 & 0.0104 \\
\hline L.S.D. & 8.68 & 8.64 & - & - & - & 7.36 & 2.77 & 8.48 \\
\hline
\end{tabular}


in the number of this pest was insignificant. According to the number of this pest, Dora proved to be the most susceptible cultivar to this pest followed by the tested cultivars which may be arranged in descending order according to their susceptibility to infestation with T. urticae to Dora (194.0), Bahi (184.16), Nemsse (179.16), CBA 910747 F1 (173.6), CBA 911264 F1 (166), Fahd (159.0) and PX 03648585 (153.25/ 30 leaves). On the other hand, in the second season 2013, it could be arranged significantly to Dora (183.91), Bahi (169.0), CBA 911264 F1 (163.0), Fahd cultivar (156.58), Nemsse (155.91), CBA 910747 F1 (147.83). PX 03648585 (135.41/30 leaves) proved to be more tolerant to the infestation with $T$. urticae.

According to the previous results in season 2012, it could be concluded that PX 03648585 cultivar proved to be the most tolerant cultivar to the infestation with the four investigated pests. Meanwhile, Fahd cultivar proved to be more tolerant to only three pests, T. tabaci, $A$. gossypii and T. urticae and was moderately sensitive to $B$. tabaci. Bahi cultivar was susceptible to the infestation with the four pests and Nemsse was only sensitive to $T$. tabaci and aphids.

In 2013, Again PX 03648585 cultivar proved to be more tolerant to infestation with the four pests. Fahd cultivar was only tolerant to the infestation with B. tabaci and T. urticae and was more sensitive to T. tabaci. Bahi cultivar was the most sensitive to the infestation with T. tabaci, B. tabaci and T. urticae and Nemsse was sensitive to $A$. gossypii. Dora cultivar was also sensitive to B. tabaci, A. gossypii and $T$. urticae.

Generally PX 03648585 was the most tolerant cultivar to the infestation with the four studied pests in both seasons and Bahi was the most susceptible one. These results are in agreement with those of Moreno et al. (1993) who screened the susceptibility of accessions comprising a range of cucurbit species and genera to infestation with $B$. tabaci and their findings indicated that all melon varieties and cucumber lines were severely infested by the pest, however, agrestis type melon Cucumis melo var agrestis genotype Gatersleben Cu M1 90/ 1982 showing low susceptibility and this parameter varied in the tested wild species. Ahmed (1994) tested six cucumber varieties (Super Dominus-hy, B.A. fomule-hy, Suner 381/hy, Celelsity/hy, conqueror/hy F1 and Sweet crunch/hy f1) for susceptibility to infestation with $A$. gossypii, T. urticae and B. tabaci. Sweet crunch/hy f1 proved to be the most resistant to the studied pests, while Super Dominus-hy was the most susceptible especially to A. gossypii. Maynard (2001) studied the varietal susceptibility of Cucurbita moschata cultivars to silverleaf whitefly (Bemisia argentifolii). Cultivars Borinquen, Linea $C$. Pinta and Soler had high incidence of silverleaf infestations in field trials. Mohamed (2012) studied the effectiveness of three varieties of cucumber (Prince, Al- 
Wafeer and Medina) on the population densities of B. tabaci (Genn.) during 2010 and 2011 seasons. The tested cucumber varieties showed significant differences in the infestation rates with $B$. tabaci nymphs. Al-Wafeer variety was the least infested one (11.04 and 8.78 nymphs/inch ${ }^{2}$ ) at the two seasons, respectively. Metwally et al. (2013) showed significant differences in the susceptibility of cantaloupe cultivars to infestation with T. tabaci, B. tabaci and T. urticae. E81-065 and Magenta cultivars were the lowest infested ones with these pests. On the other hand, Mirella variety was the highest infested cultivar.

\section{II- Laboratory studies}

1. Relationships between phytochemical contents in leaves of seven cucumber cultivars and population density of certain pests

Table (2-5) showed mean counts of four studied pest species infesting leaves of seven cucumber cultivars (Fahd, PX 03648585, Bahi, CBA 911264 F1, Dora, CBA 910747 F1 and Nemsse) in season 2013, and the correlation coefficient values between these relative population densities and the content of phytochemical components in the leaves of different cultivars.

\subsection{T. tabaci}

The studied cultivars varied significantly in their contents of total proteins, carbohydrates, lipids and reducing sugars (Table 2).

The correlation coefficients values which were calculated between the mean population density and the contents of total protein, carbohydrate, lipid and reducing sugar were significantly positive ( $r$ values $=0.66,0.76,0.58$ and 0.75 respectively) (Table 2).

The lowest seasonal mean number of $T$. tabaci occurred on the leaves of Fahd and PX 03648585 cultivar was 124.41 and 129.08 individuals/30 leaves respectively, were corresponding the low level of total protein, carbohydrate, lipid and reducing sugar in Fahd cultivar represented by $42.7,139,13.8$ and $19.3 \mathrm{mg} / \mathrm{gm}$ dry wt., respectively. Meanwhile PX 03648585 cultivar had low level of total protein (48.1 $\mathrm{mg} / \mathrm{gm}$ dry wt.), carbohydrate (141 mg/gm dry wt.), lipid (14.6 mg/gm dry wt.) and reducing sugar (29.2 mg/gm dry wt.). While the cultivars of Bahi, CBA 911264 F1, Dora, CBA 910747 F1 and Nemsse which showed higher total proteins (59.1, 69.1, 73.2, 87.3 and 93.6), carbohydrate (171, 179, 163, 190 and 190), Lipids (15.6, 16.3, 14.9, 21.9 and 22.4) and reducing sugar (40.4, 44.9, 35.4, 48.0 and 37.0) harbored higher infestation degree with T. tabaci $(143.91,131.8,135.08,140.91$ and 138.50 individuals/ 30 leaves, respectively). 


\subsection{B. tabaci}

As shown in Table 3, the highest mean seasonal population density of $B$. tabaci occurred on Bahi, CBA 911264 F1 and Dora (144.58, 129.08 and 135.58 individual/ 30 leaves, respectively) were associated with the moderate levels of total protein $(59.1,69.1$ and $73.2 \mathrm{mg} / \mathrm{gm}$ dry wt.), carbohydrate $(171,179$ and $163 \mathrm{mg} / \mathrm{gm}$ dry wt.), lipid (15.6, 16.3 and $14.9 \mathrm{mg} / \mathrm{gm}$ dry wt.) and reducing sugar (40.4, 44.9 and $35.4 \mathrm{mg} / \mathrm{gm}$ dry wt.). On the contrary, CBA 910747 F1 and Nemsse cultivars which showed higher total protein (87.3 and 93.6), carbohydrate (190 and 190), lipid (21.9 and 22.4) and reducing sugar (48.0 and 37.0) in their leaves harbored lower number of B. tabaci (109.0 and 119.4 individuals/ 30 leaves, respectively). In addition, Fahd and PX 03648585 which harbored the lowest infestation degree with B. tabaci (120.58 and 107.0) contained lower levels of total protein (42.7 and 48.1), total carbohydrate (139 and 141), total lipid (19.3 and 29.2) and reducing sugar (13.8 and 14.6).

Table 2. Relationships between the content of phytochemical components in leaves of seven cucumber cultivars and mean number of $T$. tabaci / 30 leaves during season, 2013.

\begin{tabular}{|c|c|c|c|c|c|}
\hline \multirow[b]{2}{*}{ cultivars } & \multirow[b]{2}{*}{$\begin{array}{c}\text { Mean } \\
\text { number }\end{array}$} & \multicolumn{4}{|c|}{ Phytochemical components } \\
\hline & & Total protein & Total carbohydrate & Total lipid & $\begin{array}{c}\text { Reducing } \\
\text { sugar }\end{array}$ \\
\hline Fahd & 124.41 & $42.7^{f}$ & $139^{d}$ & $13.8^{\mathrm{c}}$ & $19.3^{\mathrm{e}}$ \\
\hline PX 03648585 & 129.08 & $48.1^{\mathrm{e}}$ & $141^{\text {d }}$ & $14.6^{\mathrm{bc}}$ & $29.2^{d}$ \\
\hline Bahi & 143.91 & $59.1^{\mathrm{d}}$ & $171^{\mathrm{bc}}$ & $15.6^{\mathrm{bc}}$ & $40.4^{b}$ \\
\hline CBA $911264 \mathrm{~F} 1$ & 131.8 & $69.1^{\mathrm{c}}$ & $179^{b}$ & $16.3^{\mathrm{b}}$ & $44.9^{a}$ \\
\hline Dora & 135.08 & $73.2^{c}$ & $163^{c}$ & $14.9^{\mathrm{bc}}$ & $35.4^{c}$ \\
\hline CBA 910747 F1 & 140.91 & $87.3^{\mathrm{b}}$ & $190^{\mathrm{a}}$ & $21.9^{\mathrm{a}}$ & $48.0^{\mathrm{a}}$ \\
\hline Nemsse & 138.50 & $93.6^{\mathrm{a}}$ & $190^{\mathrm{a}}$ & $22.4^{\mathrm{a}}$ & $37.0^{\mathrm{bc}}$ \\
\hline$F$ value & 0.70 & 130.5 & 55.7 & 27.7 & 54.86 \\
\hline Pr. F & 0.64 & 0.0001 & 0.0001 & 0.0001 & 0.0001 \\
\hline L.S.D. & - & 5.048 & 8.697 & 2.06 & 3.993 \\
\hline Corr. (r) & & 0.66 & 0.76 & 0.58 & 0.75 \\
\hline Pr. (r) & & 0.10 & 0.04 & 0.16 & 0.05 \\
\hline
\end{tabular}

\subsection{A. gossypii}

In Table 4. The highest mean seasonal abundance of aphids occurred on leaves of Bahi, CBA 911264 F1, Dora, CBA 910747 F1 and Nemsse cultivars (26.58, $26.50,29.16,20.0$ and 28.41 individuals/ 30 leaves, respectively), was associated with 
high levels of total protein $(59.1,69.1,73.2,87.3$ and $93.6 \mathrm{mg} / \mathrm{gm}$ dry wt.), carbohydrate $(171,179,163,190$ and $190 \mathrm{mg} / \mathrm{gm}$ dry wt.), lipid (15.6, 16.3, 14.9, 21.9 and $22.4 \mathrm{mg} / \mathrm{gm}$ dry wt.) and reducing sugar (40.4, $44.935 .4,48.0$ and 37.0 mg/gm dry wt.), respectively. Fahd and PX 03648585 proved to be more tolerant to the infestation of this insect (16.41 and 17.50 individual / 30 leaves). These two cultivars had low amount of total protein, total carbohydrate, total lipid and reducing sugars (42.7, 139, 13.8 and $19.3 \mathrm{mg} /$ gm dry wt., respectively).

Table 3. Relationships between phytochemical components of seven cucumber cultivars and mean number of B. tabacil 30 leaves during season, 2013.

\begin{tabular}{|l|c|c|c|c|c|}
\hline \multirow{2}{*}{ Cultivars } & & \multicolumn{4}{|c|}{ Phytochemical components } \\
\cline { 3 - 6 } & $\begin{array}{c}\text { Mean } \\
\text { number }\end{array}$ & $\begin{array}{c}\text { Total } \\
\text { protein }\end{array}$ & $\begin{array}{c}\text { Total } \\
\text { carbohydrate }\end{array}$ & Total lipid & $\begin{array}{c}\text { Reducing } \\
\text { sugar }\end{array}$ \\
\hline Fahd & 120.58 & $42.7^{\mathrm{f}}$ & $139^{\mathrm{d}}$ & $13.8^{\mathrm{c}}$ & $19.3^{\mathrm{e}}$ \\
\hline PX 03648585 & 107.00 & $48.1^{\mathrm{e}}$ & $141^{\mathrm{d}}$ & $14.6^{\mathrm{bc}}$ & $29.2^{\mathrm{d}}$ \\
\hline Bahi & 144.58 & $59.1^{\mathrm{d}}$ & $171^{\mathrm{bc}}$ & $15.6^{\mathrm{bc}}$ & $40.4^{\mathrm{b}}$ \\
\hline CBA 911264 F1 & 129.08 & $69.1^{\mathrm{c}}$ & $179^{\mathrm{b}}$ & $16.3^{\mathrm{b}}$ & $44.9^{\mathrm{a}}$ \\
\hline Dora & 135.58 & $73.2^{\mathrm{c}}$ & $163^{\mathrm{c}}$ & $14.9^{\mathrm{bc}}$ & $35.4^{\mathrm{c}}$ \\
\hline CBA 910747 F1 & 109.00 & $87.3^{\mathrm{b}}$ & $190^{\mathrm{a}}$ & $21.9^{\mathrm{a}}$ & $48.0^{\mathrm{a}}$ \\
\hline Nemsse & 119.41 & $93.6^{\mathrm{a}}$ & $190^{\mathrm{a}}$ & $22.4^{\mathrm{a}}$ & $37.0^{\mathrm{bc}}$ \\
\hline F value & 2.99 & 130.5 & 55.7 & 27.7 & 54.86 \\
\hline Pr. F & 0.007 & 0.0001 & 0.0001 & 0.0001 & 0.0001 \\
\hline L.S.D. & 7.36 & 5.048 & 8.697 & 2.06 & 3.993 \\
\hline Corr. (r) & & -0.05 & 0.11 & -0.35 & 0.14 \\
\hline Pr. (r) & & 0.91 & 0.81 & 0.43 & 0.75 \\
\hline
\end{tabular}

\subsection{T. urticae}

As shown in Table 5, the highest mean seasonal abundance of $T$. urticae (egg+ moving stages) (169.0 and 183.91 individuals / 30 leaves) occurred on leaves of Bahi and Dora cultivars was related to higher levels of total protein (59.1 and 73.2 $\mathrm{mg} / \mathrm{gm}$ dry wt.), carbohydrate (171 and $163 \mathrm{mg} / \mathrm{gm}$ dry wt.) and reducing sugar (40.4 and $35.4 \mathrm{mg} / \mathrm{gm}$ dry wt.). CBA $911264 \mathrm{~F} 1$ was infested with higher numbers of T. urticae (163.08 individuals/ 30 leaves) and was associated with high amount of total protein, carbohydrate, lipid and reducing sugar $(69.1,179,16.3$ and $44.9 \mathrm{mg} / \mathrm{gm}$ dry wt., respectively). The lowest mean population density of $T$. urticae recorded on leaves of PX 03648585 (135.4) was associated with the lowest levels of total protein (48.1 $\mathrm{mg} / \mathrm{gm}$ dry wt.), carbohydrate (141 mg/gm dry wt.), lipid (14.6 mg/gm dry wt.) and reducing sugar (29.2 $\mathrm{mg} / \mathrm{gm}$ dry $w \mathrm{w}$.). 
On the contrary, CBA 910747 F1 and Nemsse cultivars which showed higher total protein (87.3 and 93.6), carbohydrate (190 and 190), lipid (21.9 and 22.4) and reducing sugar (48.0 and 37.0) in their leaves harbored lower number of $T$. urticae 147.83 and 155.9 individuals/ 30 leaves.

Table 4. Relationships between phytochemical components of seven cucumber cultivars and mean number of $A$. gossypiil 30 leaves during season, 2013.

\begin{tabular}{|l|c|c|c|c|c|}
\hline \multirow{2}{*}{ Cultivars } & \multirow{2}{*}{$\begin{array}{c}\text { Mean } \\
\text { number }\end{array}$} & $\begin{array}{c}\text { Total } \\
\text { protein }\end{array}$ & Total carbohydrate & Total lipid & Reducing sugar \\
\cline { 3 - 6 } Fahd & 16.41 & $42.7^{\mathrm{f}}$ & $139^{\mathrm{d}}$ & $13.8^{\mathrm{c}}$ & $19.3^{\mathrm{e}}$ \\
\hline PX 03648585 & 17.50 & $48.1^{\mathrm{e}}$ & $141^{\mathrm{d}}$ & $14.6^{\mathrm{bc}}$ & $29.2^{\mathrm{d}}$ \\
\hline Bahi & 26.58 & $59.1^{\mathrm{d}}$ & $171^{\mathrm{bc}}$ & $15.6^{\mathrm{bc}}$ & $40.4^{\mathrm{b}}$ \\
\hline CBA 911264 F1 & 26.50 & $69.1^{\mathrm{c}}$ & $179^{\mathrm{b}}$ & $16.3^{\mathrm{b}}$ & $44.9^{\mathrm{a}}$ \\
\hline Dora & 29.16 & $73.2^{\mathrm{c}}$ & $163^{\mathrm{c}}$ & $14.9^{\mathrm{bc}}$ & $35.4^{\mathrm{c}}$ \\
\hline CBA 910747 F1 & 20.00 & $87.3^{\mathrm{b}}$ & $190^{\mathrm{a}}$ & $21.9^{\mathrm{a}}$ & $48.0^{\mathrm{a}}$ \\
\hline Nemsse & 28.41 & $93.6^{\mathrm{a}}$ & $190^{\mathrm{a}}$ & $22.4^{\mathrm{a}}$ & $37.0^{\mathrm{bc}}$ \\
\hline F value & 3.23 & 130.5 & 55.7 & 27.7 & 54.86 \\
\hline Pr. F & 0.0046 & 0.0001 & 0.0001 & 0.0001 & 0.0001 \\
\hline L.S.D. & 2.77 & 5.048 & 8.697 & 2.06 & 3.993 \\
\hline Corr. $(r)$ & & 0.58 & 0.60 & 0.24 & 0.50 \\
\hline Pr. $(r)$ & & 0.17 & 0.14 & 0.59 & 0.24 \\
\hline
\end{tabular}

Table 5. Relationships between phytochemical components of seven cucumber cultivars and mean number of Tetranychus urticael 30 leaves during season, 2013.

\begin{tabular}{|l|c|c|c|c|c|}
\hline \multirow{2}{*}{ Cultivars } & \multirow{2}{*}{$\begin{array}{c}\text { Mean } \\
\text { number }\end{array}$} & $\begin{array}{c}\text { Total } \\
\text { protein }\end{array}$ & Total carbohydrate & Total lipid & $\begin{array}{c}\text { Reducing } \\
\text { sugar }\end{array}$ \\
\cline { 3 - 6 } Fahd & 156.58 & $42.7^{\mathrm{f}}$ & $139^{\mathrm{d}}$ & $13.8^{\mathrm{c}}$ & $19.3^{\mathrm{e}}$ \\
\hline PX 03648585 & 135.41 & $48.1^{\mathrm{e}}$ & $141^{\mathrm{d}}$ & $14.6^{\mathrm{bc}}$ & $29.2^{\mathrm{d}}$ \\
\hline Bahi & 169.00 & $59.1^{\mathrm{d}}$ & $171^{\mathrm{bc}}$ & $15.6^{\mathrm{bc}}$ & $40.4^{\mathrm{b}}$ \\
\hline CBA 911264 F1 & 163.08 & $69.1^{\mathrm{c}}$ & $179^{\mathrm{b}}$ & $16.3^{\mathrm{b}}$ & $44.9^{\mathrm{a}}$ \\
\hline Dora & 183.91 & $73.2^{\mathrm{c}}$ & $163^{\mathrm{c}}$ & $14.9^{\mathrm{bc}}$ & $35.4^{\mathrm{c}}$ \\
\hline CBA 910747 F1 & 147.83 & $87.3^{\mathrm{b}}$ & $190^{\mathrm{a}}$ & $21.9^{\mathrm{a}}$ & $48.0^{\mathrm{a}}$ \\
\hline Nemsse & 155.91 & $93.6^{\mathrm{a}}$ & $190^{\mathrm{a}}$ & $22.4^{\mathrm{a}}$ & $37.0^{\mathrm{bc}}$ \\
\hline F value & 2.86 & 130.5 & 55.7 & 27.7 & 54.86 \\
\hline Pr. F & 0.0104 & 0.0001 & 0.0001 & 0.0001 & 0.0001 \\
\hline L.S.D. & 8.48 & 5.048 & 8.697 & 2.06 & 3.993 \\
\hline Corr. $(r)$ & & 0.18 & 0.17 & -0.22 & 0.14 \\
\hline Pr. $(r)$ & & 0.69 & 0.70 & 0.62 & 0.76 \\
\hline
\end{tabular}

Generally, it can be concluded that the most susceptible cultivars which presented with high number of pests were correlated with high content of protein, carbohydrate, lipid and reducing sugar while the most tolerant one were contained mid or low amounts. 
These results are in agreement with those of Tomczyk and Kropezynska (1985) who stated that the concentration of organic compounds in the tissue of the plant leaf, i.e. proteins, carbohydrates, phenolic compounds can be influenced by mite feeding, as the reduction of total protein was occurred in the injured leaves, protein can be degenerated or its synthesis is prohibited. In addition, changes in the concentration of soluble sugars and amino acids not only create better physical conditions for feeding but also provide a higher nutritive value of the food for spider mites. Ahmed (1994) in Egypt, found the susceptible cucumber varieties to infestation with Aphis gossypii, Tetranychus urticae and Bemisia tabaci contained more protein, total amino acids, mono amino mono carboxylic acid, oxy amino acid, content of aromatic acid and basic amino acids than resistant varieties.

\section{REFERENCES}

1. Ahmed, A. M. 1994. Differences in susceptibility of six cucumber cultivars to infestation by Aphis gossypii Glov., Tetranychus urticae and Bemisia tabaci correlated to protein and amino acid contents of leaves. Ann. Agric. Sci. Moshtohor, 32 (4): 2189-2194.

2. Bradford, M. M. 1976. A rapid and sensitive method for the quantitation of microgram quantities of proteins utilizing the principle of protein- dye binding. Anal. Biochem., 72: 248- 254.

3. Crompton, M. and L. M. Birt. 1967. Changes in the amounts of carbohydrates, phosphorus and related compounds during the metamorphosis of the blowfly, Lucilia cuprina. J. Insect physiol., 13: 1575- 1595.

4. Dubois, M., K. A.Gilless, J. K. Hamilton, P. A. Rebers and F. Smith 1956. Colorimetric method for determination of sugars and related substances. Analyt. Chem., 28: 350- 356.

5. Duffus, A. 1987. Whitefly transmission of plant viruses. In Carrent Topics in Vector Research, (4): 73 - 91.

6. Knight, J. A., S. Anderson and J. M. Rawle. 1972. Chemical basis of the sulfophosphor-vanillin reaction for estimating total serum lipids. Clin. Chem., 18: 199202.

7. Marsaro Junior, A. L., P. R. V. S. Pereira and M. M. Junior. 2009. Resistance of watermelon line sources to Aphis gossypii glover (Hemiptera: Aphididae) in the state of Roraima, Brazil. Revista Academica Ciencias Agrariase Ambientais, 7(1):85-90. 
8. Maynard, D. N. 2001. Variation among tropical pumpkin (Cucurbita moschata) cultivars in susceptibility to silverleaf. Cucurbit Genetics Cooperative, (24):71-72.

9. Metwally, Samia A. G., I. F. Shoukry, M. W. F. Younes and N. M. Abd-allah. 2013. The susceptibility of certain cantaloupe cultivars to different three pests infestation in Qualyobia Governorate, Egypt. J. Agric. Res., 91 (1): 151- 167.

10. Mohamed, M. A. 2012. Impact of planting dates, spaces and varities on infestation of cucumber plants with whitefly, Bemisia tabaci (Genn.). J. Basic and Appl. Zool., 65: 17- 20.

11. Moreno, V., J. L.Gomez-Aguilera, C. Guerau-de Arellano and L. A. Roig. 1993. Preliminary screening of cucurbits species for Bemisia tabaci Genn. whitefly resistance. Report Cucurbit Genetics Cooperative, (16): 87-89.

12. Muzammil S., S. Mohammad and H. Ghulam. 2005. Impact of $\mathrm{pH}$, nitrogen and protein contents in some cucurbits on the population build-up of whitefly, Bemisia tabaci (Homoptera: Aleyrodidae). Pakistan J. Zoology. 37(4):275-279.

13. Osman, A . A. ,G. I. Zohdi and S. Abo - Kora. 1985. The role of Egyptian Clover in dispersing Tetranychid mites to cotton. Proceeding of Egypt's national conference of Entomology, 1: 141- 148.

14. Sadasivam, S. and A. Manickam. 1991. Carbohydrates. In biochemical methods for agricultural sciences. Wiley eastern limited and Tamil Nadu agricultural university, Coimbatore. 1-21.

15. SAS. 1988. Statistical Analysis System. SAS Users Guide: Statistics. SAS Institute Inc. Editors, Cary, NC.

16. Tomczyk, A. and D. Kropezynska. 1985. Effect the host plant in world crop pests, spider mites, their biology, natural enemies and control. By Hella. W. and Sabelies, M. W. Volume IA, Elsevier, Science Publishers. Amsterdam, the Nertherlands, 317-327. 


\title{
حساسية أصناف مختلفة من نبات الخيار للإصابة ببعض الأفات في محافظة الجيزة، مصر نبات الفيار
}

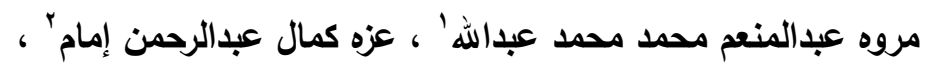

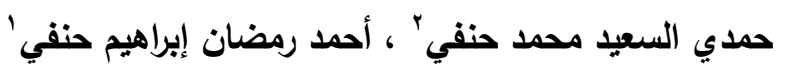

$$
\text { r- - معرد بحوث وقاية النباتات - مركز البحوث الزراعية }
$$

تهدف هذه الدراسة الحقلية والمعلية إلى تقدير مستوى حساسية سبعة أصناف من نبات الخبار وهي (Fahd, PX 03648585, Bahi, CBA 911264 F1, Dora, CBA 910747 F1 and Nemsse) للإصابة بتربس القطن والبصل وذبابة القطن والطماطم البيضاء ومن القطن والعنكبوت الأحمر ذو

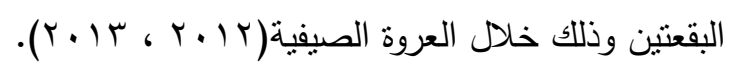

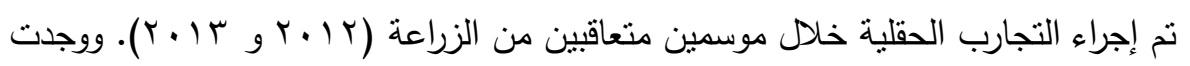

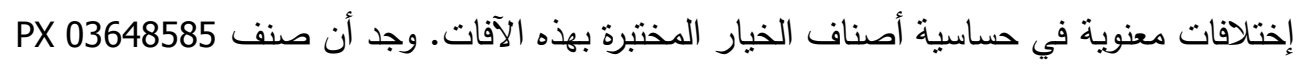

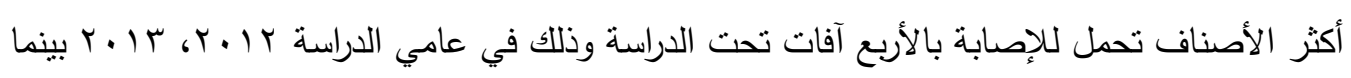
كان الصنف Bahi أكثر الأصناف حساسية للإصابة. نم تقدير محتوى بعض المكونات الكيميائية للأوراق الجافة السليمة للأصناف السبعة المختبرة

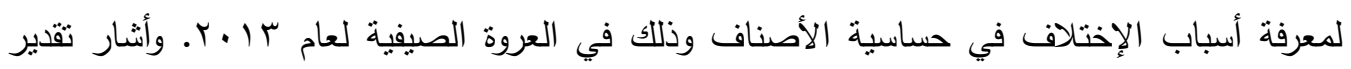
المكونات الكيميائية للأوراق غير المصابة وجود إرتباط موجب معنوي بين محتوى بعض الإفي المكونات الكيميائية ومستوى الإصابة بكلٍ من الآفات محل الدراسة. أظهرت النتائج أن الأصناف الأكثر حساسية التي تصاب الأتبات بأعداد كبيرة من الآفات إرتبطت بالمحتوى العالي من البروتين، الكربوهيدرات، الدهون والسكريات المختزلة بينما الأصناف الأكثر تحملاً هي التي إحتوت على محتوى متوسط أو أقل. 